\title{
(2) OPEN ACCESS \\ Silicone granuloma: a cause of cervical lymphadenopathy following breast implantation
}

\author{
Amarkumar Dhirajlal Rajgor 다. ${ }^{1,2}$ Youssef Mentias, ${ }^{2}$ Francis Stafford ${ }^{2}$
}

${ }^{1}$ Population Health Sciences Institute, Newcastle University, Newcastle upon Tyne, UK ${ }^{2}$ Otolaryngology \& Radiology Department, Sunderland Royal Hospital, Sunderland, UK

Correspondence to Amarkumar Dhirajlal Rajgor; amar.rajgor@newcastle.ac.uk

Accepted 11 February 2021

Check for updates

(c) BMJ Publishing Group Limited 2021. Re-use permitted under CC BY-NC. No commercial re-use. See rights and permissions. Published by BMJ.

To cite: Rajgor $A D$

Mentias Y, Stafford F. BMJ

Case Rep 2021:14:e239395.

doi:10.1136/bcr-2020-

239395

\section{SUMMARY}

We report a case of a 54-year-old woman with salinebased breast implants who presented to the ear, nose and throat neck lump clinic with a 2-week history of bilateral neck lumps. She was found to have multiple palpable cervical lymph nodes bilaterally in levels IV and $\mathrm{Vb}$. The ultrasonography demonstrated multiple lymph nodes with the snowstorm sign and a core biopsy confirmed a silicone granuloma (siliconoma). This granuloma was likely caused by bleeding gel from the silicone shell of her saline-based implants. This case demonstrates the importance of bleeding gel from salinebased implants, in the absence of implant rupture. Thus, head and neck specialists should consider siliconomas as a cause for cervical lymphadenopathy in patients with saline-based breast implants.

\section{BACKGROUND}

Cervical lymphadenopathy can be caused by an array of different pathologies. These can be categorised into either benign (eg, systemic lupus erythematosus, Epstein-Barr virus, toxoplasmosis) or malignant (eg, lymphoma, metastatic disease). ${ }^{1} \mathrm{~A}$ comprehensive history and examination is essential in elucidating the most likely diagnoses. Additionally, in high-risk patients, it is crucial to undertake appropriate investigations to rule out more sinister pathology such as head and neck cancers.

Breast implants are frequently used in both aesthetic and reconstructive breast surgery. They are composed of silicone shells filled with saline or silicone gel. ${ }^{2}$ Numerous studies have examined the safety of such implants and demonstrated the potential for ruptures, malignancies and inflammatory reactions. ${ }^{34}$ Silicone-associated lymphadenopathy occurs following migration of silicone particles to regional lymph nodes. This can be a consequence of implant rupture, or when microscopic amounts of silicone gel leak from the outer shell (known as 'gel bleed'). The majority of cases result in axillary or mediastinal lymphadenopathy. There are very few reported cases of silicone associated cervical lymphadenopathy. ${ }^{56}$

This case report both adds to the limited literature and emphasises the importance of considering silicone granulomas as a potential cause for cervical lymphadenopathy in patients with saline-based breast implants.

\section{CASE PRESENTATION}

A 54-year-old woman presented to the outpatient ear, nose and throat neck lump clinic with a 2 -week history of multiple bilateral neck lumps. These painless lumps had been progressively enlarging over a 2-week period. She had also been having episodes of night sweats but she felt these were related to her menopause. She had not noticed any other lumps around her body. She denied any weight loss and had no head and neck red flag symptoms or B-type symptoms. Additionally, she had no recent viral illness.

Thirteen years prior to presentation, she had bilateral breast augmentation with silicone-based implants. Three years following insertion, her silicone implants were recalled by the manufacturer and were replaced with saline-based implants. On removal, there was no evidence of implant rupture or leakage. She had no other relevant medical history. She was a non-smoker and consumed five units of alcohol per week.

On examination, she had multiple bilateral palpable lymph nodes in levels IV and $\mathrm{Vb}$, more prominent on the left. A flexible nasoendoscopy and oral cavity examination were unremarkable. At this stage, the differential diagnosis included lymphoma, head and neck cancer, metastases and reactive lymphadenopathy secondary to infection.

\section{INVESTIGATIONS}

The patient subsequently underwent various blood tests including a Toxoplasma gondii and Cytomegalovirus screen. These were conducted since these two opportunistic infections often have mild clinical courses and are associated with generalised

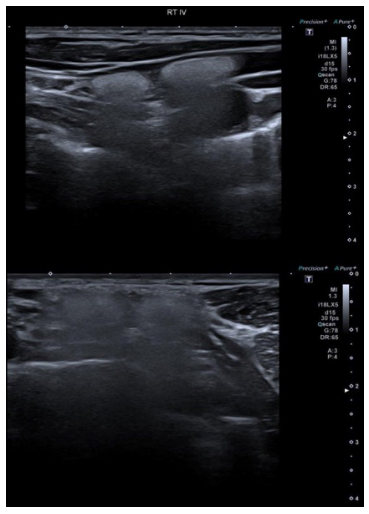

Figure 1 Ultrasonography of affected lymph nodes demonstrating the snowstorm sign ultrasonography demonstrating multiple enlarged lymph nodes with a heterogeneous echogenic pattern and dispersion of the ultrasound beam causing posterior acoustic shadowing (snowstorm sign). Features indicative of a silicone granuloma. 


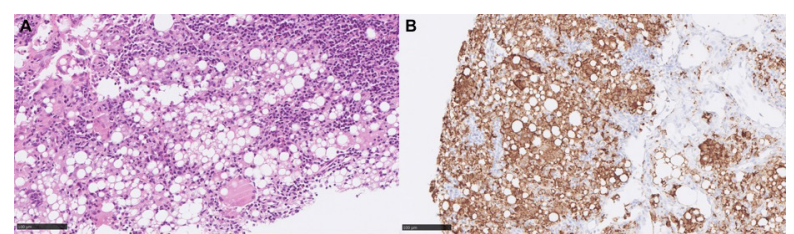

Figure 2 Photomicrograph of the silicone granuloma (A) Photomicrograph (magnification $\times 30$, H\&E stain) demonstrating numerous empty vacuoles and multinucleate giant cells. The empty vacuoles previously contained silicone, which has been dissolved during preparation of the specimen. (B) Photomicrograph (magnification $\times 30$ ) confirms the specimen is CD68 positive, a marker of macrophages.

lymphadenopathy. ${ }^{7}$ Both these screens were negative for an acute infection.

The crucial investigation in this case was an ultrasonography guided biopsy of the lymph node. The ultrasonography (figure 1) demonstrated multiple mildly enlarged lymph nodes in levels IV and $\mathrm{Vb}$ bilaterally with the largest measuring up to $1.5 \mathrm{~cm}$. There was a heterogeneous echogenic pattern with dispersion of the ultrasound beam causing posterior acoustic shadowing (snowstorm sign). A CT scan of the neck also confirmed the presence of bilateral small volume lymphadenopathy.

The core biopsy (figure 2) revealed lymph node tissue with macrophages containing large vacuoles, scattered lymphocytes and multinucleate giant cells. These findings were typical of a silicone granuloma and the silicone had most likely dissolved from the vacuoles while preparing the specimen.

\section{OUTCOME AND FOLLOW-UP}

Following discussion at the multidisciplinary team meeting (including the plastic surgery team), it was concluded that given saline-based implants are covered in a silicone shell, the lymphadenopathy was likely a consequence of gel bleeding. Subsequently, no further treatment was required. She currently remains well and has been reassured that this is not a malignant cause.

\section{DISCUSSION}

Silicone-associated lymphadenopathy occurs following the deposition of silicone in lymph nodes. Silicone can enter surrounding tissue following frank rupture of the implant or a 'gel bleed' from the outer silicone shell. ${ }^{89}$ These exposed silicone particles can subsequently migrate to regional lymph nodes through macrophages. ${ }^{10}$ Winer et al first described the histological features as a granulomatous foreign body reaction instigated by silicone particles. This results in the formation of giant cells and dense infiltration with plasma cells, lymphocytes and histiocytes. ${ }^{11}$ This inflammatory response results in lymph node enlargement.

There are numerous reported cases of silicone lymphadenopathy occurring in the mediastinum and axilla ${ }^{8912}$ but there are very few reported cases of silicone associated cervical lymphadenopathy. ${ }^{5}{ }^{13}$ Additionally, it is equally rare for saline-based implants to result in regional lymphadenopathy and this case highlights the importance of silicone gel bleeding from the outer silicone lining. Thus, for head and neck specialists it is an important differential diagnosis to consider in patients with any breast implants (since they contain a silicone outer shell). As it stands, there are currently no guidelines for the management of silicone lymphadenopathy. However, implant integrity should be evaluated by a breast specialist.
With regard to the enlarged lymph nodes, the dilemma lies in whether to opt for excision or monitor. This is a decision that should be made alongside the patient highlighting the benefits and risks of removal. In this case, as the lymphadenopathy was not causing any issues (eg, compressive symptoms, recurrent lymphadenitis/infections) no further treatment from the otolaryngologist was required.

Overall this case report demonstrates a rare presentation of cervical lymphadenopathy caused by silicone gel bleeding from saline-based breast implants. This is an entity all healthcare professionals should consider when patients with breast implants present with regional lymphadenopathy.

\section{Learning points}

- Otolaryngologists should remember the importance of bleeding gel from the silicone shell of saline-based breast implants as a cause of cervical lymphadenopathy.

- If a silicone granuloma in the neck is identified, consider imaging of the breast implant to ensure integrity.

- The importance of taking a comprehensive history to identify the differential diagnoses.

Contributors ADR was involved in the creation and revision of the manuscript and acquisition of all figures and consent from the patient.YM was involved in the revision of the manuscript and interpretation of the radiological images. FS was involved in the creation and revision of the manuscript and was the designated otolaryngology consultant in this case.

Funding This study was funded by National Institute for Health Research (NIHR) UK (ACF-2018-01-007).

\section{Competing interests None declared.}

\section{Patient consent for publication Obtained.}

Provenance and peer review Not commissioned; externally peer reviewed.

Open access This is an open access article distributed in accordance with the Creative Commons Attribution Non Commercial (CC BY-NC 4.0) license, which permits others to distribute, remix, adapt, build upon this work non-commercially, and license their derivative works on different terms, provided the original work is properly cited and the use is non-commercial. See: http://creativecommons.org/ licenses/by-nc/4.0/.

\section{ORCID iD}

Amarkumar Dhirajlal Rajgor http://orcid.org/0000-0002-9323-3107

\section{REFERENCES}

1 Bromber ME. Assessment of lymphadenopathy. BMJ Best Practice 2020 https:// bestpractice.bmj.com/best-practice/monograph/1179.htm

2 Bauer PR, Krajicek BJ, Daniels CE, et al. Silicone breast implant-induced lymphadenopathy: 18 cases. Respir Med CME 2011;4:126-30.

3 Cook PD, Osborne BM, Connor RL, et al. Follicular lymphoma adjacent to foreign body granulomatous inflammation and fibrosis surrounding silicone breast prosthesis. Am J Surg Pathol 1995;19:712-7.

4 McLaughlin JK, Lipworth L, Murphy DK, et al. The safety of silicone gel-filled breast implants: a review of the epidemiologic evidence. Ann Plast Surg 2007;59:569-80.

5 Borghol K, Gallagher G, Skelly BL. Silicone granuloma from ruptured breast implants as a cause of cervical lymphadenopathy. Ann R Coll Surg Engl 2016;98:e118-20.

6 Omakobia E, Porter G, Armstrong S, et al. Silicone lymphadenopathy: an unexpected cause of neck lumps. J Laryngol Otol 2012;126:970-3.

7 Clinical course of opportunistic Infections-Toxoplasmosis and cytomegalovirus infection in HIV-infected patients in Slovakia. Pathogens 2019;8:219.

8 Hausner RJ, Schoen FJ, Mendez-Fernandez MA, et al. Migration of silicone ge to axillary lymph nodes after prosthetic mammoplasty. Arch Pathol Lab Med $1981 ; 105: 371-2$

9 Adams ST, Cox J, Rao GS. Axillary silicone lymphadenopathy presenting with a lump and altered sensation in the breast: a case report. J Med Case Rep 2009;3:6442.

10 Tabatowski K, Elson CE, Johnston EE. Silicone lymphadenopathy in a patient with a mammary prosthesis. fine needle aspiration cytology, histology and analytical electron microscopy. Acta Cytol. Jan 1990;34:10-14.

11 Winer LH, Sternberg TH, Lehman R. Tissue reactions to injected silicone liquids. Arch Dermatol 1964;90:588-93. 
12 Brandon R, Andres Y, David K. Recurrent severe dysphagia secondary to a Siliconoma after breast implant failure. American Journal of Gastroenterology 2012;107:S262.
13 Callejo FJG, Gonzalez JC, Martinez JA. Neck lymphadenitis due to silicone granuloma after mammary implants. Acta Otorrinolaringol Esp 2013;64:217-22.

Copyright 2021 BMJ Publishing Group. All rights reserved. For permission to reuse any of this content visit

https://www.bmj.com/company/products-services/rights-and-licensing/permissions/

BMJ Case Report Fellows may re-use this article for personal use and teaching without any further permission.

Become a Fellow of BMJ Case Reports today and you can:

- Submit as many cases as you like

- Enjoy fast sympathetic peer review and rapid publication of accepted articles

Access all the published articles

Re-use any of the published material for personal use and teaching without further permission

Customer Service

If you have any further queries about your subscription, please contact our customer services team on +44 (0) 2071111105 or via email at support@bmj.com.

Visit casereports.bmj.com for more articles like this and to become a Fellow 